\title{
PENGARUH KEBISINGAN TERHADAP STRES KERJA PADA TENAGA KERJA DI INDUSTRI PENGGILINGAN PADI
}

Dian Safitri ${ }^{1 *}$

\author{
${ }^{1}$ Klinik Utama Sehat Insani Jakarta, Indonesia
}

\section{Artikel Info :}

Received 30 Juli 2021

Accepted 25 Agustus 2021

Available online 31 Agustus 2021

\section{Editor: Amrul Hasan}

\section{Keyword :}

Noise, rice miling, work stress

\section{Kata kunci :}

Kebisingan, penggilingan padi, stres kerja

\begin{abstract}
A bstract
Rice milling is one of the activities that produce high noise intensity, which can impact the health of workers. This study aims to determine the effect of noise on stress on workers at the Anugrah Mulya Rice Mill in Wates Village, Gadingrejo District, Pringsewu Regency, Lampung Province. The study used a cross-sectional design, carried out in February - May 2019. The sample is 35 workers, which is the whole of the population. Observations were made on noise sources and measured the noise level using a sound level meter. Measurements were made at 4 inside and 4 outside the room. Furthermore, interviews with workers used instruments to measure the work stress scale based on indicators or symptoms of stress, including physical symptoms, behavioral symptoms, and symptoms at work. Data were analyzed using Chi-Square statistical test. The results showed that the noise intensity in the rice milling room had exceeded the NAV of 87 $d B(A)$ and caused work stress to $51.4 \%$ of workers. Age, gender, and noise also affect work stress. Measures to reduce noise exposure in the workplace and joint recreation for all workers can prevent work-related stress.
\end{abstract}

Penggilingan padi merupakan salah satu kegiatan yang menghasilkan intensitas kebisingan tinggi yang dapat berdampak pada kesehatan pekerja. Penelitian bertujuan mengetahui pengaruh kebisingan terhadap stress pada pekerja. Penelitian menggunakan rancangan cross sectional, dilaksanakan pada bulan Februari - Mei 2019 di Penggilingan Padi Anugrah Mulya di Kelurahan Wates, Kecamatan Gadingrejo, Kabupaten Pringsewu, Provinsi Lampung. Sampel berjumlah 35 pekerja yang merupakan keseluruhan dari populasi. Observasi dilakukan pada sumber-sumber bising dan mengukur tingkat kebisingan menggunakan Sound level meter. Pengukuran dilakukan pada empat titik di dalam dan empat 4 titik di luar ruangan. Selanjutnya wawancara terhadap pekerja menggunakan instrumen untuk mengukur skala stres kerja berdasarkan indikator atau gejala stres meliputi gejala fisik, gejala perilaku, dan gejala di tempat kerja. Data dianalisis menggunakan uji statistik Chi Square. Hasil penelitian mendapatkan intensitas kebisingan di dalam ruangan penggilingan padi telah melampaui $N A B$ yaitu sebesar $87 d B(A)$ dan menyebabkan stres kerja terhadap 51,4\% pekerja. Usia, jenis kelamin dan kebisingan turut berpengaruh dengan stres kerja. Tindakan mengurangi paparan kebisingan di tempat kerja dan rekreasi bersama bagi semua tenaga kerja dapat menghindarkan tenaga kerja dari stres akibat kerja.
Ruwa Jurai: Jurnal

Kesehatan Lingkungan is licensed under a Creative Commons

Attribution-NonCommercial 4.0 International License.

\section{PENDAHULUAN}

Kesehatan kerja merupakan spesialisasi dalam ilmu kesehatan beserta praktiknya yang bertujuan agar masyarakat atau pekerja memperoleh derajat kesehatan setinggi tingginya, baik fisik maupun mental, sosial dengan usaha preventif dan kuratif, terhadap penyakit atau gangguan kesehatan yang diakibatkan faktor pekerjaan dan lingkungan serta terhadap penyakit umum (Pradana, Sudarsono, \& Subiyanto, 2013).

Menurut Peraturan Pemerintah No 50 tahun 2012, tenaga kerja adalah setiap orang yang mampu melakukan pekerjaan baik di dalam 
maupun di luar hubungan kerja, guna menghasilkan jasa atau barang untuk memenuhi kebutuhan masyarakat. Berdasarkan hal tersebut, lingkungan kerja merupakan salah satu sumber utama bahaya potensial kesehatan kerja. Salah satu dari faktor yang terdapat dalam lingkungan kerja adalah kebisingan.

Pekerjaan yang menimbulkan bising dengan intensitas tinggi umumnya terdapat di pabrik tekstil, genarator pabrik yang digunakan sebagai pembangkit tenaga listrik, pekerjaan pemotongan plat baja, pekerjaan bubut, gurinda, pengamplasan bahan logam, penggilingan padi dan sebagainya (Pradana et al., 2013).

Pada umumnya, kebisingan yang bernada tinggi sangat mengganggu, terlebih jika kebisingan tersebut berjenis terputus-putus atau yang datang hilangnya secara tiba-tiba dan tidak terduga dapat menimbulkan gangguan berupa tekanan darah, peningkatan nadi, kontruksi pembuluh darah perifer terutama pada tangan dan kaki, serta dapat menyebabkan pucat dan gangguan sensoris. Luthans (2006) dalam Utami \& Nuraini (2016) mendefinisikan stres sebagai suatu tanggapan dalam menyesuaikan diri yang dipengaruhi oleh perbedaan individu dan proses psikologis sebagai konsekuensi dari tindakan lingkungan, situasi atau peristiwa yang terlalu banyak mengadakan tuntutan psikologis dan fisik seseorang sehingga menyebabkan stres. Ada beberapa penyebab stres kerja yaitu, stresor ekstra organisasi (perubahan sosial, kesulitan menguasai globalisasi, dukungan keluarga), stresor organisasi, stresor kelompok, dan stresor individu. Disposisi individu seperti pola kepribadian tipe $\mathrm{A}$, kontrol personal. Faktor stres yang mempengaruhi seorang individu adalah beban kerja, terbatasnya waktu kerja dan peran ganda. Pola kepribadian karyawan saat mengalami stres kerja berbeda-beda.

Pada lingkungan kerja terdapat faktor fisik yang dapat mempengaruhi kesehatan jiwa dan merupakan physical environmental problem diantaranya adalah kebisingan. Laporan Badan Kesehatan Dunia (WHO) menyatakan prevalensi kehilangan atau kerusakan pendengaran di Indonesia mencapai sekitar $4.2 \%$ akibat kebisingan (WHO, 2007 dalam Rimantho \& Cahyadi, 2015). Di negara-negara maju, kebisingan merupakan masalah utama kesehatan kerja. Diperkirakan hampir $14 \%$ dari total tenaga kerja negara industri terpapar kebisingan lebih dari $90 \mathrm{~dB}$ (Oktarini, 2010).

Pusat Data dan Informasi Kesehatan RI menyebutkan bahwa jumlah kasus kecelakaan akibat kerja dari tahun 2011-2014 sangat tinggi. Pada tahun 2011 sebanyak 9.891 kasus, tahun 2012 meningkat menjadi 21.735 kasus, tahun 2013 menjadi 35.917 kasus, dan tahun 2014 sebanyak 24.910 kasus (Kemenkes RI, 2015). Faktor-faktor yang menjadi sebab kecelakaan akibat kerja meliputi golongan fisik, biologi, fisiologi dan mental psikologi. Kebisingan merupakan salah satu diantara penyebab penyakit akibat kerja dari golongan fisik (Widyastuti, 2018).

Beberapa survei mengenai stres kerja akibat dari kebisingan telah dilakukan. Survei yang dilakukan oleh Northwestren National Life menyatakan bahwa $25 \%$ pekerja yang bekerja di tempat bising mengaku mengalami stres yang sangat parah. Sedangkan survei dari Families and Work Institute menyatakan bahwa 25\% pekerja sering dan sangat sering stres oleh lingkngan pekerjaannya yang bising. Universitas Yale mengumumkan bahwa $29 \%$ pekerja melaporkan bahwa mereka merasa sakit atau sangat stres ditempat kerja akibat mesin yang bising (Kusman, Sulistiyana, \& Sari, 2015). Stres kerja adalah suatu ketegangan yang mengakibatkan ketidakseimbangan keadaan psikologis karyawan yang dapat mempengaruhi cara berpikir, emosi dan kondisi dirinya sendiri. Stres kerja terjadi karena adanya tuntutan dan tekanan yang berlebih dari tugas yang diberikan oleh perusahaan. Semakin tinggi stres kerja karyawan maka semakin buruk juga dampaknya terhadap kinerja seorang karyawan dan dapat menghambat pencapaian tujuan dan perkembangan perusahaan (Hasibuan, 2014; Mangkunegara, 2017).

Penggilingan padi merupakan salah satu kegiatan yang menghasilkan intensitas kebisingan tinggi. Berdasarkan kunjungan survei di Industri penggilingan padi Anugrah Mulya Pada tanggal 7 Januari - 9 Januari 2019. Penggilingan Padi Anugrah Mulya memiliki 2 mesin yang memproduksi beras dari kualitas standar sampai premium 5-10 Ton/harinya. 
Untuk mengerjakan pekerjaan tersebut, para tenaga kerja melakukan pekerjaan selama 9 jam/ hari (07.00-17.00 WIB) dan istirahat pada pukul 12.00-13.00 WIB. Pada jam istirahat para pekerja sebagian pulang kerumah masing-masing dan ada pula yang tetap berada diindustri penggilingan padi. Tenaga kerja yang bekerja di penggilingan padi Anugrah Mulya di kelompokkan menjadi dua kelompok, yaitu tenaga kerja bagian dalam bertugas melakukan penggilingan padi memproses padi menjadi beras, dan tenaga kerja bagian luar yang bertugas mengeringkan padi di halaman penggilingan padi. Selama proses produksi, mesin-mesin yang digunakan mengeluarkan suara bising. Besarnya intensitas kebisingan di dalam ruangan penggilingan padi adalah di atas NAB (Nilai Ambang Batas), yaitu 89 dB, 88 dB, 86 $\mathrm{dB}$ dan $83 \mathrm{~dB}$, sedangkan besarnya intensitas kebisingan diluar ruangan yaitu di halaman penggilingan padi dengan jarak $26-100 \mathrm{~m}^{2}$ dari mesin penggiling padi adalah di bawah $N A B$ (Nilai Ambang Batas), yaitu $75 \mathrm{~dB}, 73 \mathrm{~dB}, 70 \mathrm{~dB}$ dan 66 dB (Oktarini, 2010). Kebisingan dapat menyebabkan gangguan pendengaran. Gangguan pendengaran akibat bising yang timbul, terjadi secara bertahap sehingga pekerja tidak menyadarinya (Kenwa, 2019). Kebisingan yang diterima pekerja secara terus menerus dapat mengakibatkan stres kerja (Park et al., 2017). Penelitian ini bertujuan melihat pengaruh kebisingan terhadap stres kerja tenaga kerja di Industri Penggilingan Padi. Hasil penelitian diharapkan dapat menjadi acuan pengendalian risiko kebisingan di tempat kerja.

\section{METODE}

Penelitian ini merupakan studi evaluasi dengan pendekatan kuantitatif untuk mendapatkan informasi mengenai risiko keselamatan pekerja yang bekerja pada alat dibagian produksi penggilingan padi Anugrah Mulya, Pringsewu. Penelitian dilaksanakan pada bulan Februari-Mei 2019 di penggilingan padi Anugrah Mulya yang berada di Kelurahan Wates, Kecamatan Gadingrejo, Kabupaten Pringsewu, Provinsi Lampung. Populasi adalah seluruh tenaga kerja di industri penggilingan padi berjumlah 35 orang yang terbagi menjadi 2 kelompok yaitu 10 orang yang bekerja didalam ruangan dan 25 orang lainnya bekerja di luar ruangan. Seluruh pekerja diikutkan dalam penelitian.

Penelitian dilakukan dengan cara mengamati sumber-sumber bising dan mengukur tingkat kebisingan menggunakan Sound level meter. Pengukuran intensitas kebisingan dilakukan pada empat titik didalam ruangan. Titik pertama diambil pada sisi kanan mesin penggiling padi, titik kedua pada sisi kiri mesin penggiling padi, titik ketiga pada sisi kanan tumpukan sementara beras, dan titik keempat pada sisi kiri tumpukan sementara beras. Di luar ruangan penggilingan, titik pertama pada sisi kanan depan ruang penggilingan padi, titik kedua pada sisi kiri depan ruang penyimpanan beras, titik ketiga pada sisi belakang kanan tembok pagar, dan titik keempat pada sisi belakang kiri tembok pagar.

Wawancara dilakukan terhadap seluruh pekerja menggunakan questioner stres Terry Looker dan Olga Gregson. Instrumen ini untuk mengukur skala stres kerja berdasarkan indikator atau gejala stres kerja meliputi gejala fisik, gejala perilaku, dan gejala di tempat kerja. Analisis statistik dilakukan dengan uji Chi Square.

\section{HASIL}

Penggilingan padi Anugrah Mulya Pringsewu merupakan industri sedang yang berdiri sejak tahun 1999. Lahan penggilingan padi seluas $5000 \mathrm{~m}^{2}$, dengan luas bangunan sekitar $450 \mathrm{~m}^{2}$. Pabrik beroperasi Senin hingga Minggu, setiap hari beroperasi selama 9 jam, dari pukul 07.0017.00 WIB dengan istirahat 1 jam, pada pukul 12.00-13.00 WIB. Mesin produksi yang dimiliki oleh penggilingan padi Anugrah Mulya sebanyak empat unit, terdiri dari dua unit mesin pemecah kulit dan dua mesin pemutih. Seluruh mesin yang digunakan dalam proses produksi penggilingan padi berada di dalam ruangan penggilingan padi. Setiap harinya penggilingan padi Anugrah Mulya menghasilkan 5-10 Ton/harinya beras. Penggilingan padi ini selain menghasilkan beras sebagai hasil produksi utama, serta menghasilkan katul, menir dan sekam sebagai produksi sampingnya.

Tabel 1 menjelaskan tenaga kerja paling banyak berada pada usia 36-45 tahun (71,4 \%), mayoritas laki-laki (77,1\%). Pekerja dengan tingkat pendidikan rendah yaitu sebanyak 82,9 $\%$ dan pendidikan tinggi 17,1\%. Pada 
pengukuran stres kerja, terdapat 51,4\% pekerja mengalami stres kerja.

Tabel 1. Karakteristik Pekerja

\begin{tabular}{lll}
\hline Karakteristik & $\mathrm{n}$ & $\%$ \\
\hline Usia & & \\
$\quad$ 36-45 Tahun & 25 & 71,4 \\
25-35 Tahun & 10 & 28,6 \\
Jenis Kelamin & & \\
$\quad$ Laki-laki & 27 & 77,1 \\
$\quad$ Perempuan & 8 & 22,9 \\
Pendidikan & & \\
$\quad$ Rendah & 29 & 82,9 \\
$\quad$ Tinggi & 6 & 17,1 \\
Kebisingan & & \\
$\quad$ Merasa bising & 25 & 71,4 \\
$\quad$ Tidak merasa bising & 10 & 28,6 \\
\hline
\end{tabular}

Berdasarkan Tabel 2, rata-rata intensitas kebisingan di dalam ruangan penggilingan padi adalah $87 \mathrm{~dB}(\mathrm{~A})$ dan di halaman penggilingan padi adalah $72 \mathrm{~dB}(\mathrm{~A})$. Angka tersebut menunjukkan bahwa intensitas kebisingan dalam ruangan telah melebihi Nilai Ambang Batas (NAB). Menurut Kementerian Tenaga Kerja RI (2018), NAB kebisingan adalah $85 \mathrm{~dB}(\mathrm{~A})$ untuk waktu kerja terus menerus tidak lebih dari 8 jam/ hari atau $40 \mathrm{jam} / \mathrm{ming}$.

Tabel 2. Hasil pengukuran Intensitas Kebisingan

\begin{tabular}{llll}
\hline Lokasi Pengukuran & Mean & SD & $\begin{array}{l}\text { Minimal- } \\
\text { Maksimal }\end{array}$ \\
\hline Dalam ruangan & 87 & 2,94 & $83-90$ \\
Luar ruangan & 72 & 7,07 & $63-80$ \\
\hline
\end{tabular}

Tabel 3 menggambarkan stres kerja di Pabrik penggilingan padi Anugerah Mulya. Sebanyak $51,43 \%$ pekerja mengalami stres kerja dan 48,57\% pekerja tidak mengalami stres kerja.

Tabel 3. Stres kerja pada pekerja

\begin{tabular}{lcc}
\hline Stress kerja & Frekuensi & Persentase (\%) \\
\hline Stres Kerja & 18 & 51,43 \\
Tidak Stres Kerja & 17 & 48,57 \\
\hline
\end{tabular}

Tabel 4 menjelaskan, pada kelompok pekerja yang berusia 25-35 tahun terdapat 68\% mengalami stres kerja dan 32,2\% tidak mengalami stres kerja. Sedangkan pada kelompok usia 25-35 tahun terdapat 10,0\% mengalami stres kerja dan $90 \%$ tidak mengalami stres kerja. Hasil uji statistik memperoleh nilai $p$ value $=0,003 ; \mathrm{OR}=19,125(2,056-177,921)$. Hal ini dapat diartikan bahwa terdapat hubungan yang bermakna antara usia dengan stres kerja. Pekerja berusia 36-45 tahun lebih berisiko mengalami stres kerja dibanding pekerja dengan usia 25-35 tahun.

Pada kelompok pekerja berjenis kelamin lakilaki, terdapat $63,0 \%$ mengalami stres kerja dan $37,0 \%$ tidak mengalami stres kerja. Sedangkan pada kelompok wanita terdapat $12,5 \%$ mengalami stres kerja dan 87,5 tidak mengalami stres kerja. Laki-laki lebih berisiko stres akibat kerja dibanding perempuan ( $p$-value $=0,018$; $\mathrm{OR}=11,900,95 \% \mathrm{Cl} 1,272-111,351)$.

Tabel 4. Pengaruh Kebisingan dan karakteristik pekerja dengan Stres Kerja

\begin{tabular}{|c|c|c|c|c|c|c|}
\hline \multirow{2}{*}{ Variabel } & \multicolumn{2}{|c|}{ Stres } & \multicolumn{2}{|c|}{ Tidak stres } & \multirow{2}{*}{ p. value } & \multirow{2}{*}{ OR (CI 95\%) } \\
\hline & $\mathrm{n}$ & $\%$ & $\mathrm{n}$ & $\%$ & & \\
\hline Usia & & & & & \multirow{3}{*}{0,003} & \multirow{3}{*}{$\begin{array}{c}19,125 \\
(2,056-177.921)\end{array}$} \\
\hline 36-45 Tahun & 17 & 68,0 & 8 & 32,2 & & \\
\hline 25-35 Tahun & 1 & 10,0 & 9 & 90,0 & & \\
\hline Jenis Kelamin & & & & & \multirow{3}{*}{0,018} & \multirow{3}{*}{$\begin{array}{c}11,900 \\
(1,272-111,351)\end{array}$} \\
\hline Laki-laki & 17 & 63,0 & 10 & 37,0 & & \\
\hline Perempuan & 1 & 12,5 & 7 & 87,5 & & \\
\hline Pendidikan & & & & & \multirow{3}{*}{0,088} & \multirow{3}{*}{$\begin{array}{c}7,083 \\
(0,731-68,609)\end{array}$} \\
\hline Rendah & 17 & 58,6 & 12 & 41,4 & & \\
\hline Tinggi & 1 & 16,7 & 5 & 83,3 & & \\
\hline Kebisingan & & & & & \multirow{3}{*}{0,027} & \multirow{3}{*}{$\begin{array}{c}7,111 \\
(1,234-40,984)\end{array}$} \\
\hline Bising & 16 & 64,0 & 9 & 36,0 & & \\
\hline Tidak Bising & 2 & 20,0 & 8 & 80,0 & & \\
\hline
\end{tabular}


Faktor pendidikan tidak berpengaruh terhadap stres kerja. Pada kelompok pekerja yang merasakan bising terdapat 64,0\% mengalami stres kerja dan 36,0\% tidak mengalami stres kerja, sedangkan pada kelompok pekerja yang tidak merasa bising terdapat 20,0\% mengalami stres kerja dan 80,0\% tidak mengalami stres kerja. Pekerja yang merasakan bising berisiko untuk mengalami stres kerja sebesar 7,111 kali dibanding pekerja yang tidak merasakan bising ( $p$-value $=0,027$; $\mathrm{OR}=7,111,95 \% \mathrm{Cl}=1,234-40,984)$.

\section{PEMBAHASAN}

Usia merupakan salah satu faktor yang dapat mempengaruhi tingkat stres yang dialami oleh seseorang. Meskipun demikian, penelitian mengenai pengaruh umur terhadap tingkat stres kerja masih belum jelas dan hasilnya berbedabeda. Hasil penelitian ini menunjukkan ada hubungan yang bermakna antara usia dengan stres kerja dengan $p$ value 0,003 (tabel 3 ), dan OR 19,125. Artinya usia 36-45 tahun lebih berisiko stres akibat kerja sebesar 19,125 kali dibanding usia 25-35 tahun. Hasil ini juga dibuktikan oleh Zulkifli et al. (2019) yang menyebutkan bahwa ada hubungan yang bermakna antara usia dengan stres kerja. Akan tetapi berbeda dengan penelitian pada pekerja industri di Jerman yang menunjukkan tidak ada hubungan antara umur dan gejala stres akut (Rauschenbach, Krumm, Thielgen, \& Hertel, 2013).

Tingkat stres yang dialami pekerja muda (< 35 tahun) cenderung rendah dan mulai mengalami peningkatan hingga mencapai puncak stres kerja pada pekerja usia menengah (36-45 tahun). Perbedaan tingkat stres ini dipengaruhi oleh tuntutan kerja yang cenderung berbeda pada masing-masing kelompok umur sehingga menghasilkan tingkat stres kerja yang berbeda-beda (Schlick, Frieling, \& Wegge, 2013). Pekerja berumur tua cenderung mengalami stres yang lebih tinggi akibat beban kerja dan tanggung jawab yang besar. Pada penelitian ini, faktor tanggung jawab dan beban kerja yang harus diemban oleh pekerja adalah sama, baik pekerja yang berusia muda maupun tua. Hal ini dapat terjadi karena pekerja dengan usia yang lebih muda cenderung mempunyai kondisi kesehatan yang lebih baik dibanding pekerja dengan usia yang lebih tua (Zulkifli et al., 2019). Semakin bertambah usia seseorang akan semakin rentan mengalami stres, karena semakin kompleksnya persoalan yang dialami. Responden dengan umur lebih muda cenderung untuk menanggulangi stres kerja karena perbedaan cara kerjanya dengan pekerja lainnya (Irkhami, 2015).

Hasil wawancara kepada pekerja dapat dijelaskan bahwa stres kerja yang dialami pekerja berupa peningkatan tekanan darah, gangguan konsentrasi, cepat marah dan ketidaknyamanan di telinga. Pengendalian stres dapat dilakukan oleh pemilik pabrik penggilingan padi melakukan kegiatan-kegiatan santai seperti jalan-jalan ke pantai atau ke tempat hiburan lain. Kegiatan dapat dijadwalkan sedikitnya 1 tahun sekali agar pekerja dapat merasa santai dan rileks.

Jenis kelamin merupakan salah satu faktor yang dapat menimbulkan stres di tempat kerja. Dari Tabel 1 didapatkan bahwa jumlah responden yang berjenis kelamin perempuan (22,9\%) lebih sedikit dibandingkan dengan jumlah responden laki-laki (77,1\%). Berdasarkan hasil analisis bivariat, variabel jenis kelamin berhubungan signifikan dengan stres kerja yang dialami para pekerja di industri penggilingan padi ( $p$ value $=0,018$; $O R=11,900,95 \% \mathrm{Cl} 1,272$ 111,351). Hasil ini sejalan dengan hasil penelitian Amalia et al. (2017) dan Ansori \& Martiana (2017) yang menyatakan ada hubungan antara jenis kelamin dengan stres kerja. Lebih lanjut Amalia dan Ansori menyebutkan bahwa perempuan lebih berisiko untuk mengalami stres kerja dibanding laki-laki. Pernyataan ini bertolak belakang dengan hasil penelitian. Pada penelitian ini, laki-laki berisiko mengalami stres kerja sebesar 11,900 kali dibanding perempuan. Bisa jadi disebabkan karena mayoritas pekerja pada industri penggilingan padi berjenis kelamin laki-laki. Mengatasi stres pekerja di pabrik penggilingan padi dapat dilakukan dengan sesama pekerja saling memberikan dukungan sosial, misalnya saling membantu pekerjaan, memberikan pengarahan atau saran terhadap permasalahan di tempat kerja. Hal ini juga dapat dilakukan oleh pemilik usaha penggilingan. 
Faktor kondisi individu seperti umur, jenis kelamin, dan pendidikan dapat menyebabkan terjadinya stres kerja (Nahrio, 2019). Pendidikan juga dipandang sebagai salah satu faktor yang berpengaruh dengan stres kerja. Akan tetapi, dalam penelitian ini tidak dapat dibuktikan. Dari Tabel 1 terlihat, mayoritas pekerja berpendidikan rendah (82,9\%). Hasil analisa bivariat pada Tabel 3 mendapatkan $p$-value $=0,088$. Hal ini disebabkan tingkat pendidikan karyawan di pabrik penggilingan padi rata-rata sama sehingga setiap karyawan mempunyai pengetahuan, keterampilan dan tanggung jawab yang sama untuk menyelesaikan pekerjaan. Secara konseptual, pendidikan merupakan segala sesuatu untuk membina kepribadian dan mengembangkan kemampuan manusia baik formal maupun informal. Karena setiap penggunaan teknologi hanya akan dapat kita kuasai dengan pengetahuan, keterampilan, dan kemampuan yang handal (Tarwaka, Bakri, \& Sudiajeng, 2004). Industri disarankan melakukan pembinaan dan penyuluhan tentang pentingnya alat pelindung diri dan melakukan diskusi ataupun evaluasi untuk para pekerja agar menambah wawasan serta pengetahuan pekerja, terutama pekerja yang tingkat pendidikannya rendah.

Oktarini (2010) menjelaskan bahwa stres akibat kerja secara lebih sederhana adalah stres yang terjadi karena suatu ketidakmampuan pekerja dalam menghadapi tuntutan tugas yang mengakibatkan ketidaknyamanan dalam kerja. Sehingga, dampak dari stres kerja akan mengakibatkan menurunnya performance, efisiensi dan produktivitas kerja tenaga kerja yang bersangkutan. Kebisingan atau suara yang tidak diinginkan, dianggap sebagai polusi pekerjaan, terutama yang keras atau tidak menyenangkan atau yang menyebabkan gangguan terhadap manusia dan sekitarnya. Kebisingan kerja adalah kebisingan yang dikeluarkan dari berbagai industri yang mempengaruhi keselamatan dan kesehatan pekerja. Berkepanjangan Paparan terhadap kebisingan dapat membawa efek negatif pada reseptor, sehingga menimbulkan kebisingan penyakit gangguan pendengaran.

Hasil pengukuran kebisingan yang disajikan tabel 2, di dalam ruangan pabrik sebesar 87 $d B(A)$ sedangkan diluar pabrik sebesar $72 d B(A)$. Kondisi kebisingan di dalam pabrik telah melampaui ambang batas. Hasil menunjukkan ada hubungan yang signifikan antara antara kebisingan dan stres kerja ( $p$-value $=0,027$; $\mathrm{OR}=7,111,95 \% \mathrm{Cl}=1,234-40,984)$. Jumlah tenaga kerja yang terpapar kebisingan di atas NAB lebih banyak mengalami stres kerja di bandingkan tenaga kerja yang terpapar kebisingan di bawah $N A B$. Sedangkan jumlah tenaga kerja yang terpapar kebisingan di bawah NAB akan berkurang atau lebih sedikit mengalami stres kerja dibandingkan dengan yang terpapar kebisingan di atas NAB. Hasil ini didukung penelitian lain yang menyatakan terdapat hubungan yang signifikan antara intensitas kebisingan dengan stres kerja pada pekerja (Irawan, 2015; Kusman et al., 2015; Oktarini, 2010). Hasil dari penilaian stres kerja menunjukkan bahwa 64\% pekerja yang terpapar bising mengalami stres kerja.

Kebisingan merupakan salah satu faktor bahaya fisik yang sering di jumpai di lingkungan kerja (Kementerian Tenaga Kerja RI, 2018). Kebisingan merupakan masalah kesehatan kerja yang selalu timbul pada industri besar. Nilai Ambang Batas faktor fisika dan kimia tentang kebisingan adalah sebesar $85 \mathrm{~dB}$ untuk pemaparan 8 jam sehari, dan 40 jam seminggu. Kebisingan didefinisikan sebagai segenap bunyi yang tidak di kehendaki. Temuan dari penelitian ini penting sebagai dasar dalam upaya menyediakan lingkungan kerja yang lebih kondusif bagi karyawan dan secara tidak langsung meningkatkan produktivitas perusahaan (Firdaus, 2020; Mansor et al., 2020). Industri disarankan untuk penggunaan peredam pada sumber bising, penyekatan (ruang mesin dibatasi dengan sekat dinding semi permanen contohnya triplek), ataupun pengaturan tata letak ruang dan penggunaan alat pelindung diri seperti ear plug sehingga kebisingan tidak mengganggu kesehatan atau membahayakan. Tindakan mengurangi paparan kebisingan di tempat kerja dan rekreasi bersama bagi semua tenaga kerja dapat menghindarkan tenaga kerja dari stres akibat kerja. 


\section{SIMPULAN}

Intensitas kebisingan di dalam ruangan penggilingan padi telah melampaui Nilai Ambang Batas (NAB) yaitu $87 \mathrm{~dB}(\mathrm{~A})$. Penelitian menemukan sebanyak $51,4 \%$ pekerja mengalami stres kerja akibat paparan kebisingan secara terus menerus. Usia, jenis kelamin dan kebisingan turut berhubungan dengan stres kerja $(p$-value $<0,05)$. Pengendalian stres dapat dilakukan oleh pemilik pabrik penggilingan padi dengan menyediakan alat pelindung diri seperti ear plug, memberikan peraturan wajib menggunakan alat pelindung diri sesuai kebutuhan tempat kerja, melakukan rotasi dan mengatur jam kerja, melakukan kegiatankegiatan santai seperti jalan-jalan ke pantai atau ke tempat hiburan lain. Sesama pekerja saling memberikan dukungan sosial, misalnya saling membantu pekerjaan, memberikan pengarahan atau saran terhadap permasalahan di tempat kerja. Hal ini juga dapat dilakukan oleh pemilik usaha penggilingan.

\section{DAFTAR PUSTAKA}

Amalia, B. R., Wahyuni, I., \& Ekawati. (2017).

Hubungan Antara Karakteristik Individu, Beban Kerja Mental, Pengembangan Karir Dan Hubungan Interpersonal Dengan Stres Kerja Pada Guru Di SLB Negeri Semarang. Jurnal Kesehatan Masyarakat (e-Journal), 5(5), 68-78.

Ansori, R. R., \& Martiana, T. (2017). Hubungan Faktor Karakteristik Individu Dan Kondisi Pekerjaan Terhadap Stres Kerja Pada Perawat Gigi. The Indonesian Journal of Public Health, 12(1), 75. https://doi.org/10.20473/ijph.v12i1.2017.75-84

Firdaus, J. (2020). The Potension of Aditory Nerve Damage on Milling Industry Workers in Jember Regency. Journal of Agromedicine and Medical Sciences, 6(1), 62. https://doi.org/10.19184/ams.v6i1.16717 Hasibuan, S. M. (2014). Manajemen Sumber Daya Manusia (Edisi Revi). Jakarta: Bumi Aksara. Irawan, P. (2015). Studi Deskriptif Kebisingan Dan Stres Kerja Pada Pekerja Penggilingan Padi Di Kecamatan Sawangan, Kabupaten Magelang Jawa .... Universitas Negeri Semarang.

Irkhami, F. L. (2015). Factor Associated with Job Stress in Divers at PT X. The Indonesian Journal of Occupational Safety and Health, 4(1), 54-63.

Kemenkes RI. (2015). Situasi Kesehatan Kerja. In Infodatin Kemenkes RI (1st ed.). Retrieved from https://www.kemkes.go.id/download.php?file $=d$ ownload/pusdatin/infodatin/infodatin-kesja.pdf Kementerian Tenaga Kerja RI. Peraturan Menteri Tenaga Kerja No 5/2018 K3 Lingkungan Kerja. , 5 Permenakertrans $\S$ (2018).

Kenwa, M. M. L. (2019). Hubungan Intensitas Kebisingan Dengan Tingkat Stres Kerja Pada Pekerja Bengkel Motor Dan Dealer Dwijati Motor Denpasar. Jurnal Medika, 8(5), 25978012.

Kusman, A., Sulistiyana, C. S., \& Sari, S. H. (2015). Hubungan Antara Kebisingan dengan Gangguan Pendengaran pada Pekerja Penggilingan Beras. Jurnal Kedokteran Dan Kesehatan, 2(1), Cirebon.

Mangkunegara, A. A. A. P. (2017). Manajemen Sumber Daya Manusia Perusahaan (Cetakan ke). Bandung: PT. Remaja RosdaKarya.

Mansor, A. A., Abdullah, S., Ahmad Nawawi, M. A., Ahmed, A. N., Mohd Napi, N. N. L., \& Ismail, M. (2020). Temporal and Spatial Analysis of the Occupational Noise at Rice Mill in Kedah. IOP Conference Series: Earth and Environmental Science, 498(1), 4-11. https://doi.org/10.1088/17551315/498/1/012094

Nahrio. (2019). Studi Intensitas Kebisingan pada Penggilangan Padi di Kelurahan Dodu Kecamatan Rasanae Timur Kota Bima. Politeknik Kesehatan Kemenkes Kupang.

Oktarini, I. (2010). Pengaruh Kebisingan Terhadap Stress Kerja Tenaga Penggilingan Padi CV Padi Mamur Karanganyar. Universitas Sebelas Maret.

Park, J., Chung, S., Lee, J., Sung, J. H., Cho, S. W., \& Sim, C. S. (2017). Noise sensitivity, rather than noise level, predicts the non-auditory effects of noise in community samples: A populationbased survey. BMC Public Health, 17(1), 1-9. https://doi.org/10.1186/s12889-017-4244-5

Peraturan Pemerintah No 50 tahun 2012. Peraturan Pemerintah Republik Indonesia No. 50 Tahun 2012 Tentang Penerapan Sistem Manajemen Keselamatan dan Kesehatan Kerja. , Sekretarian Negara § (2012).

Pradana, B., Sudarsono, B., \& Subiyanto, S. (2013). Analisis Kesesuaian Lahan Pertanian Terhadap Komoditas Pertanian Kabupaten Cilacap. Jurnal Geodesi Undip, 2(2), 82849.

Rauschenbach, C., Krumm, S., Thielgen, M., \& Hertel, G. (2013). Age and work-related stress: a review and meta-analysis. Journal of Managerial Psychology, 28(7/8), 781-804.

https://doi.org/10.1108/JMP-07-2013-0251 
Rimantho, D., \& Cahyadi, B. (2015). Analisis Kebisingan Terhadap Karyawan Di Lingkungan Kerja Pada Beberapa Jenis Perusahaan. Jurnal Teknologi, 7(1), 21-27.

Schlick, C., Frieling, E., \& Wegge, J. (2013). AgeDifferentiated Work Systems: Introduction and Overview to a Six-Year Research Program in Germany. In Age-Differentiated Work Systems (1st ed.). https://doi.org/10.1007/978-3-64235057-3_1

Tarwaka, Bakri, S. H. A., \& Sudiajeng, L. (2004). Ergonomi untuk Keselamatan, Kesehatan Kerja dan Produktivitas (Ed 1). Surakarta: UNIBA PRESS.

Utami, T. N., \& Nuraini. (2016). Analisis Spiritual Value, Stres Kerja Pekerja Muslim Sektor Formal Kota Medan. Jurnal Jumantik, 1(1), 1-24.

Widyastuti, A. D. (2018). Hubungan Stres Kerja Dengan Kelelahan Kerja Pada Pekerja Area Workshop Konstruksi Box Truck. The Indonesian
Journal of Occupational Safety and Health, 6(2), 216-224. https://doi.org/10.20473/ijosh.v6i2.2017.216224

Zulkifli, Z., Rahayu, S. T., \& Akbar, S. A. (2019). Hubungan Usia, Masa Kerja dan Beban Kerja Dengan Stres Kerja Pada Karyawan Service Well Company PT. ELNUSA TBK Wilayah Muara Badak. KESMAS UWIGAMA: Jurnal Kesehatan Masyarakat, 5(1), 46-61.

https://doi.org/10.24903/kujkm.v5i1.831 